\title{
Achieving National Security in Nigeria through Education
}

\author{
Seji D.O. Omoroje, Philip Onyekachukwu Egbule \\ \& John Ejime Emuebie \\ http://dx.doi./org/10.4314/ujah.v21i4.8
}

\section{Abstract}

This paper discusses how Nigeria as a nation can achieve national security through, not just education, but qualitative education. National security has been described in this paper, as freedom from or resilience against potential harm caused by others. For easy comprehension and assimilation, the paper was strategically broken down into six, (6) distinct sections, to wit; conceptualization of key words, causes of insecurity in Nigeria, effects of insecurity in Nigeria, role of education in checkmating insecurity, previous efforts by governments to address insecurity issues and; conclusion and recommendations. The paper was able to establish the fact that quality education can reduce incidences of insecurity, even if not totally eradicated. Education, this paper revealed is a major weapon of progressive social change. The paper concludes that sound education anchored on good educational policies and implementation can reduce, to a manageable extent, insecurity in Nigeria. Therefore some recommendations, such as declaring a state of emergency in the educational sector to reduce illiteracy, were proffered. This, the paper suggested, among others will provide a panacea for the problem of insecurity in Nigeria.

\section{Introduction}

The term National Security became prominent in Nigerian society during the upheavals that followed the political imbroglio of 1966 which heralded the Nigerian civil war, beginning from 1967-1970. The word gained ascendency and became a household parlance in our 
polity at the return to civil democracy in 1999, following the withdrawal of the military from the active politics and governance of the country. There is no gainsaying the fact that Nigeria is currently facing serious security challenges, that have put every citizen on the edge including those at the helm of affairs and even the security operatives saddled with the responsibility of securing lives and properties. Hardly can fellow countrymen and women sleep with their two eyes closed. Since the last four years, there has been a dramatic twist on the wave, dynamics and sophistication of insecurity in Nigeria. Insecurity that used to be one of the lowest concerns in the hierarchy of Nigeria's social problems has now assumed an alarming proportion. A time we thought that corruption and power failure have the crown of our problems, insecurity in the country has now taken the centre stage (FinIntell, 2013).

Fear, apprehension and jitteriness have become the lot of Nigerians. Consequently, huge amount of money is always allocated to security by government for the purpose of addressing these threats of insecurity. A cursory glance at the Nigerian daily newspapers will convince one of the states of insecurity in the country. Youth restiveness, kidnapping, bombing, arson, militancy, insurgency inter alia, have become the order of the day (Ogheneakoke, 2014). National growth, economic development and human capital development have all been hampered by this social problem. Robert McNamara, a onetime president of the World Bank, once observed that no country can develop under an environment of insecurity. Peace and stability, to him, are necessary condition for growth and development. As seen in Nigeria, Mordi (2013) noted that the nation's growth and stability have been truncated by the on-going mayhem and destruction of lives and property in different parts of the country by the menace of BokoHaram in the Northern states, the militants and kidnappers in the south-South; among others. Food production has been grossly affected and on the decline as farming and agricultural activities have 
been hampered, while oil exploration, exploitation and export have been negatively affected in the North and south-south, respectively (Omoroje, 2012).

In light of these, we shall be discussing how to achieve national security in Nigeria, in this paper, under the following subheadings:

1. Conceptualization of key words

2. Causes of insecurity in Nigeria

3. Effects of insecurity in Nigeria

4. Role of education in checkmating insecurity

5. Previous efforts made by governments to address insecurity.

6. Conclusion and recommendations

\section{Conceptual Clarification of Key Words National Security}

We cannot define national security without, first of all, conceptualizing the word security. Wikipedia defined security as freedom from, or resilience against, potential harm (or other unwanted coercive change) caused by others. (https//en.m.wikipedia.org), Nmom (2013) described this term security as a total peaceful state of mind of an individual, the group, the state, the nation at a particular point in time and space. He reasoned that it may not be an absence of violence or some sort of physical assault or some disruptions but a relative peace that can guarantee quality life and social cohesion for survival of the individual group or nation. From the above two definitions, one can deduce that security is perceived in terms of protecting the generality of the people, and it is a collective responsibility of the government and the people. Hence, the notion of community policing has become a recurrent decimal in security parlance in Nigeria. According to Mezieobi (2012) the term security brings to mind issues that pertain, 
predominantly, to one or a combination of the following whenever it is discussed:

a. The defence and protection of national integrity or Nigeria's sovereignty, territorial and political jurisdictions from external and internal interferences or intervention;

b. Personal safety of members of political class who are in control of the helm of affairs of governance, in addition to safeguarding or protecting their office, hence the incredible allocation of funds for security services;

c. The security agents or forces, civil defence corps protecting the lives and properties of the mass of the defenseless citizenry against the menace of the men of the underworld;

d. Forestalling or deterring possible internal attacks or crises and subjugating insurgency;

e. Keeping the security agents on active security alert and readiness at all points in time;

f. Checkmating impending or actual internal threats to state or national security or anti-social behaviours by those who are deliberately undermining or sabotaging government efforts;

g. Checkmating social problems such as Boko-Haram saga and youth militancy, kidnapping/abduction that may pose threat to state and national security and detract the political cadre in control of state affairs from active commitment to their functions; and;

h. Making the environment free from insecurity in order to attract international investment. This is in line with Robert McNamara's earlier quoted assertion on the relationship between growth, national development and peace and security.

From the definitions above, security therefore can mean the state of being free from danger, risk or threat. It covers freedom from anxiety, fear, the safety of a state or organization against criminal activities and attacks like terrorism, theft or espionage (Ogheneakoke, 
2014). The security interests of any nation therefore include safety of lives and properties, economic, physiological, mental well-being and the freedom to pursue the attainment of objectives without hindrance (Otoibhi, 2012).

In the opinion of Brown (2013), National security is the ability to preserve the nation's physical integrity and territory, to maintain its economic relations with the rest of the world on reasonable terms, to preserve its nature, institutions and governance from outside disruption, and to control its borders. Also, national security is a condition where our most cherished values and beliefs, our democratic way of life, our institutions of governance and our unity, welfare and well-being as a nation and people are permanently protected and continuously enhanced. It is the requirement to maintain the survival of the nation through the use of quality education, economic power, military and political power, diplomacy and power projection. It can be described as the aggregation of the security interest of the individuals, political entities, human associations and ethnic groups which make up the nation (Osakwe, 2013). Succinctly put, national security is the security of a nation state, including its citizens, economy, and institutions, which is regarded as a duty of government (https//en.m.wikipedia.org).

National security therefore refers to policy enacted by governments to ensure the survival and safety of the nation-state, including but not limited to the exercise of diplomatic, economic and military power in both peace and war. In other words, it means the freedom from foreign domination which is the sine-qua-non for the sustenance of the state through the instrumentality of economic, diplomacy, power projection and political power.

\section{Insecurity}

The term insecurity can be conceptualized according to the discipline or subject of study. For instance, Nigerians talk of insecurity when 
describing a state or situation of declining safety of lives and properties, apprehension over increasing rate terrorism, armed robbery, kidnappings, political upheavals, religious conflicts, assassinations, secret cults-related criminal acts, intra and inter ethnic strife, hijacking, riots, demonstrations, etc. But for the purpose of this study, we will adopt the definition of Effiom and Edinyang (2013) who defined insecurity as the state of being subjected to danger and injury. It is a feeling of un-usual nervousness that may be triggered by perceiving of oneself to be vulnerable.

\section{Education}

Education is very important to the development of any society. In fact, according to Freire (1970) education is a major weapon of social change and should not be neglected by any human society that craves for development in all ramifications of the word. The Nigerian government recognizes the importance of education to the overall growth of the nation and "as instrument for effecting national development" to the extent that the Nigeria's philosophy of education is based on the following set of beliefs:

a. Education is an instrument for national development and social change

b. Education is vital for the promotion of a progressive and united Nigeria

c. Education maximizes the creative potentials and skills of the individual for self-fulfillment and general development of the society.

d. Education is compulsory and a right of every Nigerian irrespective of gender, social status, religion, colour, ethnic background and any peculiar individual challenges: and

e. Education is to be qualitative, comprehensive, functional and relevant to the needs of the society (FGN, 2004). 
Scholars, over time, have added an adjective, "quality" in a bid to conceptualize the term education. They opined that for education to achieve its stated goals, it must be qualitative. Hence, Maduewesi (2002) opined that quality education demands that all levels and aspects of the educational system, including but not exclusive to, vocational, practical and theoretical education, should produce results that are of much benefit to the nation. It involves factors such as well articulated national goals, well planned curriculum, assessment procedure and instruments, capacity to examine data, how to utilize assessment results and quality of students enrolled. To him, the challenge of quality education is lack of good parenting and a belief among many of the youths and adults in our society that education and hard work to achieve it are not critical components in life.

UNICEF (2000), clarifying what quality education should be, emphasizes that this education type should incorporate:

i. Learners who are healthy, well-nourished and ready to participate and learn, and who are supported in learning by their families and communities

ii. Environments that are healthy, safe, protective and gender sensitive, and that provide adequate resources and facilities

iii. Content that is reflected in relevant curricular and material for the acquisition of basic skills, especially in the areas of literacy, numeric skills for life and knowledge of nutrition, HIV/AIDs prevention and peace.

iv. Process through which trained teachers use child-centred teaching approaches in well-managed classrooms and schools and skillful assessment to facilitate learning and reduce disparities

v. Outcome that encompasses knowledge, skills and attitudes, and are linked to national goals for education and positive participation in society. 
UNESCO (2005), another body established by the United Nations (UN), while writing in the same vein, opined that quality education is expected to encourage the learners' creative and emotional development; support objective of peace, citizenship and security; promote quality; seek for past global and local cultural values and transfer them to future generations. Omo-Ojuga (2007) and Ajegbesan (2010) observe that quality education addresses major domains which reflect diverse goals and audience including the promotion and improvements of basic education, re-orientation of existing educational policies and programmes at all levels to address national security and sustainable development, development of public awareness as well as provision of training and retraining, which should involve higher education.

Therefore, education must be wholistic, encompassing qualitative and quantitative processes which must include "relevant curriculum, availability of adequate human and non-human resources, assessment of educational programmes and processes through proper supervision and evaluation of educational outcomes to ensure quality assurance, control and nation security (Osakwe, 2013).

\section{Causes of Insecurity in Nigeria}

Ogheneakoke (2014) identified a plethora of factors as causes of insecurity in Nigeria. These include, but not limited to, the following:

i. Corruption

ii. Marginalization

iii. Social inequality

iv. Ethnicity

v. Poverty and greed

vi. Loss of value system

vii. Religious intolerance

viii. Foreign infiltration - insurgency

ix. Bad leadership 
x. Youth unemployment

xi. Porosity of our boarders

xii. Falling standard of education

xiii. Poor judiciary system

xiv. Cultism and cult activities

xv. High value for material things

xvi. Manipulation of electoral processes by political parties

xvii. Lack of trust on security agents

xviii. Human right abuses

xix. Injustice

xx. Lack of transparency

\section{Cost and Effects of Insecurity in Nigeria}

The socio-political and economic landscape in Nigeria has been blighted by the endemic twin evil of crime and violence. The abysmal failure of successive administrations in Nigeria to address challenges of poverty, unemployment and inequitable distribution of wealth among ethnic nationalities, ultimately resulted to anger, frustration, agitation and violent crimes against the Nigerian state by individuals and groups. Such crimes include militancy, kidnapping, bombing, armed robbery, destruction of government properties, among others. The activities of various militia groups consequently resulted in low income for government from oil revenue, moderating the gross domestic product growth rate, low participation of local and foreign investors in economic development and insecurity of lives and properties of the citizens (Finintell, 2013).

\section{The Cost}

The cost of life and material resources to insecurity in the country since the past few years is unquantifiable. According to Human Rights Watch, a security monitoring agency, between 2009 and 2012, about 2,000 lives had been lost to militia insurgency; within the first 
nine months in 2012, 815 people were killed in 275 suspected attacks, and more than 60 police stations were attacked in 10 northern states, excluding the bombed police headquarters in Abuja. Tens of dozens are still nursing various degrees of injuries. The data base of orphans and widows caused by the rampaging sects has grown vastly, swelling the numbers of internally displaced persons (IDPS).

Money from some international organization and funds raised locally from governmental, nongovernmental agencies, charitable organizations and individuals that is supposed to be channelled to human capital development has been deployed for the rehabilitation of families of the causalities and the renovation of properties destroyed. Yearly, unspecified millions of naira is being paid as ransom for the release of victims of kidnappers: not forgetting the Central Bank of Nigeria's N100 million cash donation, N200million donation from the combined efforts of the opposition governors, and the $\$ 50,000$ (USD) from the Christian Association of Nigeria (CAN), America chapter, to reduce the suffering of the victims of regional militia.

The cost of insecurity in Nigeria could also be seen on the percentage of annual budget allocated to security agencies on yearly basis. Infrastructure and human capital development are almost foregone alternatives; hence capital expenditure is struggling from the rear. (See diagram 1 below)

\section{The Weight of Insecurity on National Budget}

\begin{tabular}{|l|l|l|l|l|}
\hline S/N & Year & $\begin{array}{c}\text { Budget } \\
\text { (N'trn) }\end{array}$ & $\begin{array}{c}\text { Allocation to } \\
\text { Security (N'bn) }\end{array}$ & $\begin{array}{c}\text { \% on } \\
\text { Budget }\end{array}$ \\
\hline 1 & 2013 & 4,987 & 668 & 13 \\
\hline 2 & 2012 & 4,888 & 922 & 19 \\
\hline 3 & 2011 & 4,972 & 1,040 & 21 \\
\hline 4 & 2010 & 4,239 & 448 & 11 \\
\hline 5 & 2009 & 3,049 & 176 & 6 \\
\hline
\end{tabular}


(Source: FinIntell, 2013)

\section{The Effect}

As Nigeria struggles with the army of unemployed youths of about $24 \%$, companies in their numbers are closing down operations in Boko-Haram ravaged north and oil-rich south-south, and relocating to other African countries for loss of lives and properties. And the few remaining companies operate on skeletal bases. Construction workers and expatriates providing specialized services on various projects in these regions have fled for safety. This development has multiplied the number of unemployment youth roaming the street and has become an easy tool for violence. This scenario has not only deepened the existing unemployment rate but also paints a gloomy picture of poverty.

Education they say is the bedrock of social economic development (Freire, 1970). The Islamic militants have serially attached students and facilities in educational institutions in different northern states in the country (Chibok Girls and Burnin Yadin Boys Government Schools). Over time, a lot of schools have shut down their academic programmes. This has drastically impacted the teaming number of students seeking admission into academic institutions at all levels. For example, university of Maiduguri, one of the most affordable universities in Nigeria which is known for turning down admission of students because of quality and to avoid overcrowding of facility, now solicits for admission through different media outreach.

Also recently, a respondent survey shows that many students have vowed never to participate in the compulsory one year national youth service corps (NYSC) programme if posted to the northern part of the country. Those who were inadvertently posted to the north redeployed immediately after three weeks of mandatory camping. 
This development therefore defeats the core mandate of setting up the Act of NYSC in 1973 (FinIntell, 2013).

The growth of foreign direct investment in tourism sector had been adversely affected as some immigration departments of countries in Europe and America have issued warnings to their citizens who wish to visit Nigerian to be aware of the security problem in the country. Not only did insecurity in the country affect foreign direct investment, it affects business confidence as many companies lost confidence in establishing businesses in some parts of the country; see diagram below:

Diagram II: The $1^{\text {st }}$ quarter 2013 business confidence Index (BCI)

\begin{tabular}{|l|c|c|c|}
\hline \multicolumn{4}{|c|}{ Business/Investment Destination in 2013 } \\
\hline S/N & State & No of Response & \% of Total \\
\hline 1 & FCT & 392 & 27 \\
\hline 2 & Rivers - PH & 332 & 23 \\
\hline 3 & Ogun - Industrial & 123 & 8 \\
\hline 4 & Oyo - Ibadan & 114 & 8 \\
\hline 5 & Delta & 80 & 5 \\
\hline 6 & Anambra - Onitsha & 39 & 3 \\
\hline 7 & Abia - Aba & 35 & 2 \\
\hline 8 & Enugu & 35 & 2 \\
\hline 9 & C/River - Calabar & 33 & 2 \\
\hline 10 & Akwa Ibom - Uyo & 32 & 2 \\
\hline & Total & $\mathbf{1 . 4 7 5}$ & $\mathbf{1 0 0}$ \\
\hline
\end{tabular}

Source: Lagos Chamber and Commerce and Industries (LCCI)

The report above shows the confidence of entrepreneurs on the destination in the country they wish to expand or establish new business with Lagos as an exception. Abuja and Port-Harcourt accounted for $50 \%$ of alternative business destinations in Nigeria in 2013. Sadly, no northern city made it to the top 15 alternative investment destinations in 2013. No doubts, the northern region has 
overtime, enjoyed the lion share of insecurity. Also, as security situation in the country becomes more worrisome, the respect of Nigeria in the eyes of the international community diminishes. It engenders stiffer conditions in bilateral relations. If urgent steps are not taken to address this ugly trend, it will negatively affect all the indices of development and the quest for millennium development goal, and vision 2020 will be mirage (FinIntell, 2013).

\section{Role of Education in Checking Insecurity}

There is a significant relationship between national security and education. a cursory look at the personality of Boko-Haram Islamists and bandits in the northern region of Nigeria reveals high level or rate of illiteracy among them. It is in the light of this that the Emir of Kano, HRM Lamido Sanusi, admonished the elites of the region to establish schools, instead of building mosques. Also, in a bid to help reduce the rate of illiteracy the past administration of Dr. Goodluck Jonathan established Nomadic education and Al-Majari schools in the northern region.

According to Nandi (2013), education helps in developing intelligent social actors with the ability to make rational decisions and act intelligently. It also helps to address issues of poverty, violent crimes and illiteracy. Through education, the moral personality of man is built up as it equips leaner with the skills of moral judgment that in turn guides his actions and behaviours. In other words, the right type of values such as honesty, respect for elders, integrity inter alia is inculcated into the young ones. Quality education also promotes the spirit of nationalism and patriotism among youths. Through education, it has been discovered that youths develop positive attitudes of togetherness, comradeship and cooperation towards the entire nation.

UNESCO (2008) stated that "No development can be possible without humans, and no humans can reach development without 
quality education". It is in light of this, that Anadi (2008) opined that for a nation to be developed and secured, there must be a very considerable proportion of trained educated citizens in that nation not only to act as doctors, engineers, teachers, agriculturist, scientists, and the likes, but also to create a new class sufficiently large and hence, sufficiently strong to establish its own values of justice, security, selection on merit, flexibility, empiricism and efficiency. For this to be actualized, our education system (primary, secondary and tertiary levels) must be practical and functional. Therefore, quality education is the primary agents of national security and development for bringing the vision of society into reality. "For example, if the militants, Boko-Haram, armed robberies and kidnapers were properly nurtured with quality formal, informal and indigenous education from the grass root level, all these security threats/challenges such as terrorism, riots/civil unrest, demonstrations, intolerance, cult-related criminal acts, religious intolerance, arm robbery, intra and inter-ethnic strife, drug trafficking, human trafficking, kidnapping, hijacks and many other vices threatening lives and properties would not have been in existence" (Osakwe, 2013).

\section{Previous Effort by Government to Check Insecurity}

The inability of the security agencies to address the country's security challenges has raised some critical questions on the preparedness of Nigeria to attain desired political, social and economic heights in the year 2020. It further poses serious threats to the unity and corporate existence of Nigeria as a sovereign state (FinIntell, 2013).

Over the years, successive governments in Nigeria have adopted several measures aimed at addressing challenges of insecurity in the country, ranging from the carrots and sticks measures to the use of outright force and periodic critical evaluation of the performance of security agencies saddled with the responsibility of handling the situation. These security agencies include: 
i. The National Security Agency (NSA)

ii. The National Intelligence Agency (NIA)

iii. The State Security Service (SSS)

iv. The Nigeria Police Force (NPF)

v. The Nigeria Immigration Service (NIS)

vi. The Nigeria Customs Service (NCS)

vii. The National Drug Law Enforcement Agency (NDLEA)

viii. The Nigeria Security and Civil Defence Corps (NSCDC)

ix. The Nigeria Army - comprising of the Army, Air force and navy

In 1987, the Gen. Ibrahim Babangida administration established the Directorate of mass mobilization of social justice, selfreliance and economic Recovery (MAMSER), which later dovetailed into the National Orientation Agency (NOA) under the civilian administration of President Olusegun Obasanjo. Among the objectives of these government agencies are to:

i. Encourage informal education through public enlightenment activities and publications.

ii. Establish appropriate national framework for educating, orienting and indoctrinating Nigerians towards developing socially desirable attitudes, values and culture, which project individual's national pride and positive national image for Nigeria:

iii. Develop among Nigerians of all ages and sex, social and cultural values and awareness that will inculcate the spirit of patriotism, nationalism, self-discipline and self-reliance.

iv. Promote new sets of attitudes and culture for the attainment of the goals and objectives of a united Nigerian state.

$\mathrm{v}$. Instill in the populace a sense of absolute loyalty to the fatherland'

vi. Ensure and uphold leadership by example; and 
vii. Foster respect for constituted authority (Oloya and Egbule, 2016).

Apart from these agencies established to give Nigerians proper orientation towards love for the fatherland, the government has set up various interventionist commissions and agencies like Oil Mineral Producing Areas Development Commission (OMPADEC), the Niger Delta Development Commission (NDDC), Ministry of Niger Delta Affairs (MNDA), the Amnesty Programme for Repentant Militants who surrender arms to the military authorities, and recently, the North East Development Commission (NEDC). According to Osaghae, (1995), all these programmes though established with the intension of ensuring the development, proper integration and progress of these agitation-pruned regions, the many years of practical deprivations, despair and failure of these interventionists policies has overtime created a feeling of frustration among the people. He therefore concluded that factually speaking, some people have accused the federal government of promoting unrealistic projects and policies serving no useful purpose other than being a conduit pipe for siphoning oil wealth, for instance they have faulted the established of the ministry of the Niger Delta Affairs (MNDA) alongside the Niger Delta Development Commission (NDDC) and the Amnesty Programme.

Lastly, there has been a proliferation of vigilante security outfits (both private and government owned) in the states, in a bid to yield to the call by citizens to adopt community policing to support the conventional security apparatuses. This comes against the backdrop of the refusal of successive government in Nigeria to establish State Police to compliment the efforts of the Nigerian Police Force, which is controlled by the National government and which they reasoned lacks grass root touch. 


\section{Conclusion and Recommendations}

Although the achievement of total or absolute security would be a mirage or to say the least an exercise in futility, as no country in the world or any known human society has achieved such an enviable feat. The contemporary security challenges in the country have not only raised critical questions bordering on the formulation, implementation and execution of Nigeria's educational policies cum philosophy, and internal security policies, but also the effectiveness of the security agents to perform their statutory responsibilities with patriotism. On the basis of this, this paper recommends the under listed points/suggestions, as panacea for this seemingly intractable insecurity challenges in Nigeria:

- The Federal Government (FG) should formulate and effectively implement policies and programmes capable of addressing the root causes of insecurity in Nigeria - such as high level of illiteracy, poverty, unemployment, environmental degradation, dearth of infrastructural facilities, uneven development, among others.

- The government should phase out the National Poverty Eradication Programme (NAPEP) and establish a more viable and result-oriented agency or even radically declare a state of emergency in the educational sector of the country. This we hope will be capable of addressing the problem of mass illiteracy leading to abject poverty among large population of Nigerians, particularly those residing in the rural areas.

- The government should resuscitate the National Directorate of Employment (NDE) and reposition the agricultural sector so as to play active role in job creation for Nigerian youths. This is where quality vocational education/skill acquisition comes into play as we earlier postulated in this paper; establishment of technical schools and polytechnics should be given priorities when educational policies are being formulated. 
- There is a need for collective security arrangement by all levels of government in Nigeria - Federal, State and Local governments. The current arrangement where security apparatuses are totally in control by the central/federal government needs to be looked into and redressed. This is where the issue of community policing comes into focus. This security configuration should produce a committee at village, community, local, state and federal levels with the responsibility of providing sensitive security information for security agencies at their areas of operation. This will ultimately assist in identifying criminals, their sponsors and hideouts in the country.

- Lastly, the FG should reorganize the country's intelligence system and build a capable and more proactive security apparatus in Nigeria. This will add more values in checking incessant bombings, robbery, kidnapping and violent crimes/crises by hoodlums in the country.

- For all these to be achieved, quality education for the masses is key.

Seji D.O. Omoroje, Philip Onyekachukwu Egbule \& John Ejime Emuebie

Social Studies Department, College of Education, Agbor pastorp4christ@gmail.com omoroje@yahoo.co.uk 


\section{References}

Anadi, C.C. (2008). Governments and Education in Nigeria: Concern for Sustainable National Development: In C. Maduka and O.A. Afemikhe (Eds.) Issues in Education, Government and Development. Benin-City: Institute of Education, University of Benin.

Brown, $\mathrm{H}$.

(2013).

National

Security: http://en.wikipedia.org/wiki/nationalsecurity. Retrieved 7th June, 2013.

Effiom, V.N. and Edinyang, S.D. (2013). Social Studies and National Transformation, Nigeria Journal of Social Studies and Civil Education, 3(1): 138-149.

Federal Government of Nigeria (2004), National Policy on Education, Lagos: NERDC Press.

FinIntell, (2013). The Cost and Effect of Insecurity in Nigeria; Culled from http://www.financialintelligence.com/professionalservices. Retrieved 12/09/2019, 12.20pm.

Freire P. (1970). Pedagogy of the Oppressed; Herder and Herder' New York.

Mezieobi, K.A. (2012). New Frontier Areas in Social Studies in Nigeria, Owerri: Acadapeak Publishers.

Mordi, C. (2013). Educational Reformation for National Security. Keynote Address presented at the Annual Conference of the Institute of Education, Delta State University, Abraka, Held from $11^{\text {th }}-15^{\text {th }}$ of June, 2013.

Nandi, Y. (2013) Preventing Conflict and Ensuring National Security in Nigeria through Social Studies, Nigerian Journal of Social Studies and Civic Education, 4(1), 120-134.

Nnom, O.C. (2013). Nigerian Family Values Amidst Security Challenges, Nigeria South-South Journal of Social Studies and Civic Education 8(6), 86-96. 
Ogheneakoke, E.C. (2014). Social Studies and National Security, in W.P. Akpochafo and D.I. Mezieobi (ed.), Social Studies and National Security in Nigeria, Enugu; Oshilo Consults.

Oloya, B.O. and P.O. Egbule (2016). Globalization and the Crisis of Nation Building in Nigeria, Agbor: Jimtech Prints.

Omoroje, O.D. (2012). The Political Economy of Militancy in the Niger-Delta Region of Nigeria (1999-2011); Unpublished Ph.D Thesis Proposal.

Osaghae, E.E. (1995). The Ogoni Uprising: Oil Politics, Minority Agitation and the Future of the Nigerian State: Afri Affairs 94 (376).

Osakwe, N.R. (2013). Achieving National Security and Development through Quality Education in Nigeria, Research Journal in Education, 19(1), 80-83.

Otoibhi, B. (2012). Resolving National Security Challenges: Our Reader, July $5^{\text {th }} 2012$.

United Nations Children Education Fund (2004); A World Fit for Children: UNICEF, Geneva.

United Nations Education and Scientific Organization (2005). Education for all, Global Monitoring Report 2005. UNESCO; Paris.

Wikipedia (2019) National Security. Retrieved Sept. $11^{\text {th }} 2019$ from http://en.m.wikipedia.org/wiki/nationalsecurity. 